\title{
Subsurface particle transport shapes the deep critical zone in a granitoid watershed
}

\author{
X. Gu ${ }^{1,2 *}$, H. Kim ${ }^{2,3}$, S. Hynek ${ }^{2,4}$, A. Thompson ${ }^{5}$, S.L. Brantley ${ }^{1,2}$
}

\begin{abstract}
OPEN (2) ACCESS
Abstract

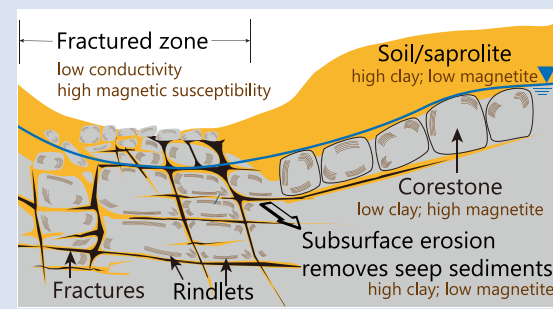
ticle transport may thus contribute to geophysical signatures and help sustain high weathering fluxes at Río Icacos and other steep and highly fractured landscapes.

Understanding the inter-relationships between chemical weathering and physical erosion remains a first order puzzle in Earth surface dynamics. In the Río Icacos watershed in the Luquillo Critical Zone Observatory, Puerto Rico, where some of the world's fastest weathering of granitoid watersheds has been measured, we show that chemical weathering not only releases dissolved solutes, but also weakens the rock around the fractures until particles detach and are mobilised by subsurface flow through fractures. These sand-sized particles are more weathered than corestones, but much less weathered than soils/saprolites. Subsurface removal of these clayenriched, magnetite-depleted particles from the fractures could explain zones with
\end{abstract}

Received 21 March 2021 | Accepted 20 August 2021 | Published 7 October 2021

\section{Introduction}

In watershed studies, identification of the input and output components of a mass balance model is the first and the most critical step to quantify fluxes and their importance in the evolution of the critical zone-the layer from the canopy of the trees to the groundwater (Chadwick et al., 1990; Riebe et al., 2017). However, many models are based on incorrect a priori assumptions, and end up neglecting important fluxes. For example, most denudation studies are based on the assumption that subsurface losses occur only through the chemical mobilisation of solutes with physical erosion only important for the mobile soil layer (see Riebe et al., 2017 and references therein). However, soil and sediment particles also move below the land surface and even below the soil layer. Subsurface particle transport has been discussed by geomorphologists (e.g., Dunne, 1990), but weathering implications have only been highlighted in a few locations (e.g., Bern et al., 2015; Kim et al., 2018).

To explore the significance of subsurface particle transport in the Luquillo Mountains, Puerto Rico at a site where such transport has been noted (Harrison et al., 2020), we examined "seep sediments" collected from a seep along a steep slope and stream sediments from stream beds in the Río Icacos watershed. As one of the fastest weathering and eroding granitoid systems in the world (White and Blum, 1995), this site has been well studied (White et al., 1998; Buss et al., 2008; Shanley et al., 2011; Comas et al., 2019), allowing us to elucidate how sub- surface particle transport contributes to shaping the deep critical zone.

\section{Weathering in the Río Icacos Watershed}

The Río Icacos is a bowl-shaped $3.26 \mathrm{~km}^{2}$ watershed located in the headwaters of the Río Blanco in the Luquillo Mountains of northeastern Puerto Rico (Fig. 1a). This humid, montane tropical forested watershed is almost exclusively developed on the Río Blanco Quartz Diorite, a pluton that contains predominantly plagioclase and quartz (White et al., 1998). In Río Icacos, it has been well documented that spheroidal weathering, initiated by biotite oxidation and volume expansion, fractures to form $\mathrm{cm}$-sized, onion-like rindlets that wrap around increasingly spheroidal corestones (Buss et al., 2008). Each rindlet is characterised by fine microcracks and is separated from other rindlets by larger macro-cracks. The zone of rindlets ( $\sim .5-1 \mathrm{~m}$ in thickness) transforms to the thick layer of overlying saprolite and soil. In the following, we first discuss the potential importance of seep sediments and then present evidence for the mechanism of their formation.

\section{Characteristics of Seep and Stream Sediments}

Seep sediments were sampled from a perennial seep emanating from between corestones in a roadcut wall along Route 191

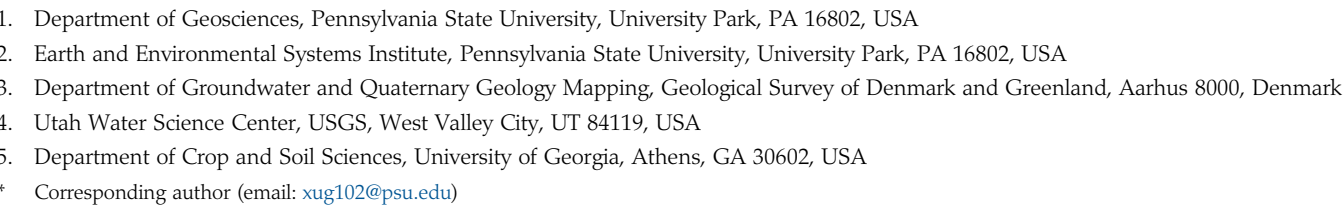


(Fig. 1b), situated on a steep slope from mountain top to river bottom. The weekly yield of seep sediments produced at the seep during the sampling periods (August-November, 2016) varied by more than one order of magnitude and showed positive correlations with peak discharge and peak rainfall (Fig. 2). The particle size distribution of seep sediments, which varies with discharge (Fig. S-1), is dominated by particles in the upper sand size range (median size: $0.4-1.6 \mathrm{~mm}$ ). Dissolved Si concentrations in water sampled at the seep during the study measured $375 \pm 35 \mu \mathrm{M}$, consistent with groundwater that has circulated to tens of metres depth (cf. Shanley et al., 2011; Hynek et al., 2017).

Twelve stream sediment samples were collected from beds of the Río Icacos and Quebrada Guaba (an Icacos tributary draining Guaba Ridge, Fig. 1a). The geochemical, mineralogical, and textural signatures indicate the stream sediments are likely mixtures of seep sediments + soils/saprolites. As shown by Buss et al. (2008), the composition of the quartz diorite changes as it is transformed first into rindlets, then saprolite, and ultimately soil. Specifically, the extent of depletion in $\mathrm{Ca}$ and $\mathrm{Na}$ (increasing depletion of plagioclase) increases roughly from corestone to rindlet to seep sediment to stream sediment to soil/saprolite (Fig. 1c). The X-ray diffraction (XRD) patterns and the grain size distributions show the same trends, consistent with weathering extent in these materials (Supplementary Information). Similarly, the concentrations of cosmogenic ${ }^{10} \mathrm{Be}$ in stream sediments at Río Icacos are lower as compared to the soils (Brown et al., 1995; Brocard et al., 2015). These results are consistent with stream sediments in the Río Icacos deriving not only from soils, but also from less weathered materials. These materials were previously assumed to have been delivered by landslides scouring material from depth (Brown et al., 1995; Dosseto et al., 2014). Here, we propose an alternative or additional pathway that these materials are transported as particles through the subsurface.

The characteristics of the seep sediments allow us to constrain the sources of stream sediments at Río Icacos. Assuming that 1) stream sediments are composed of soil/saprolite plus a less weathered component, 2) Al is not solubilised during chemical weathering, and 3) the less weathered component is chemically similar to seep sediments, we estimated $46 \pm 22 \%$ and $88 \pm 10 \%$ of $\mathrm{Na}$ and $\mathrm{Ca}$ in the stream sediments at the gages
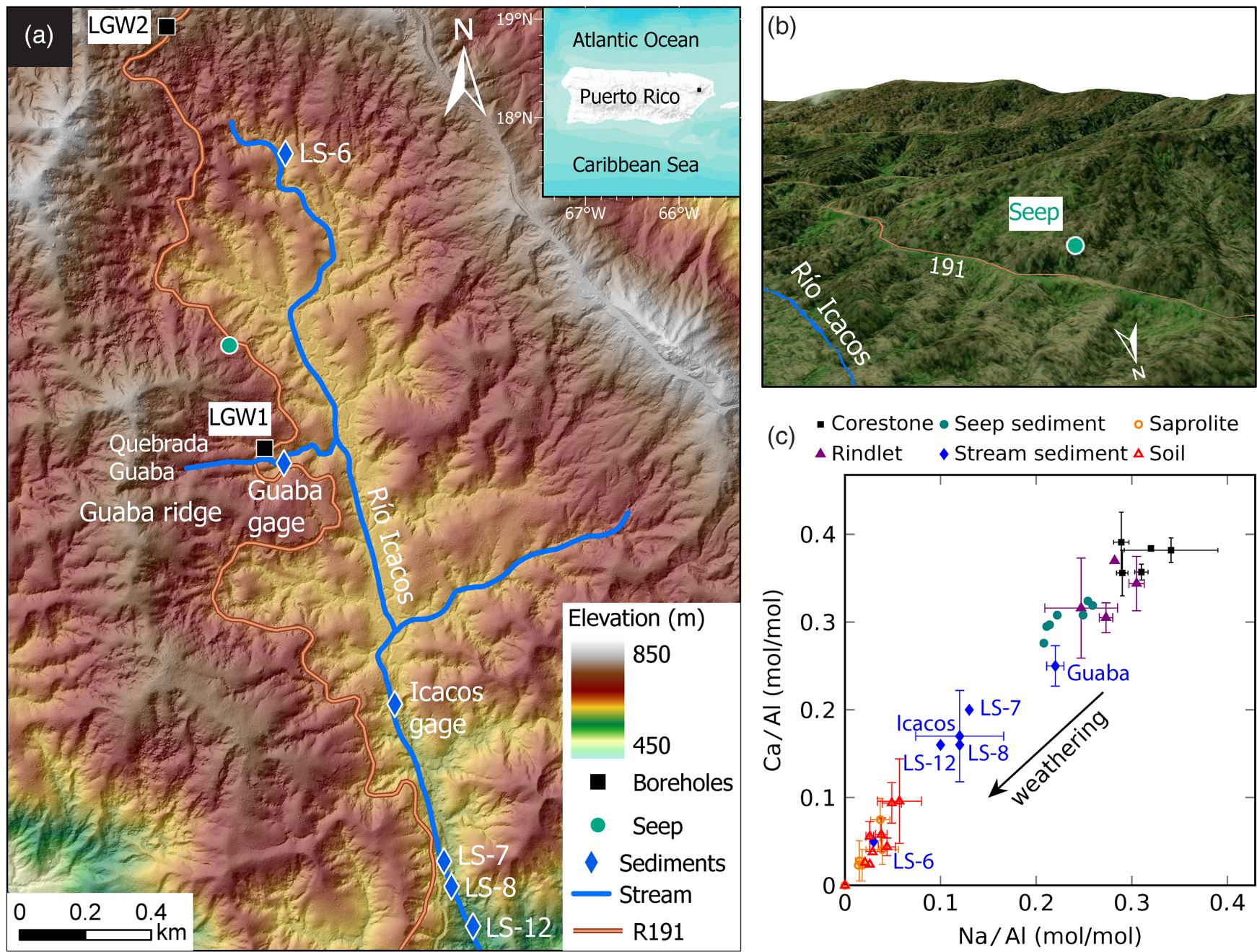

(c) - Corestone $\bullet$ Seep sediment oSaprolite

(c)

\section{$\Delta$ Rindlet $\quad$ Stream sediment $\Delta$ Soil}

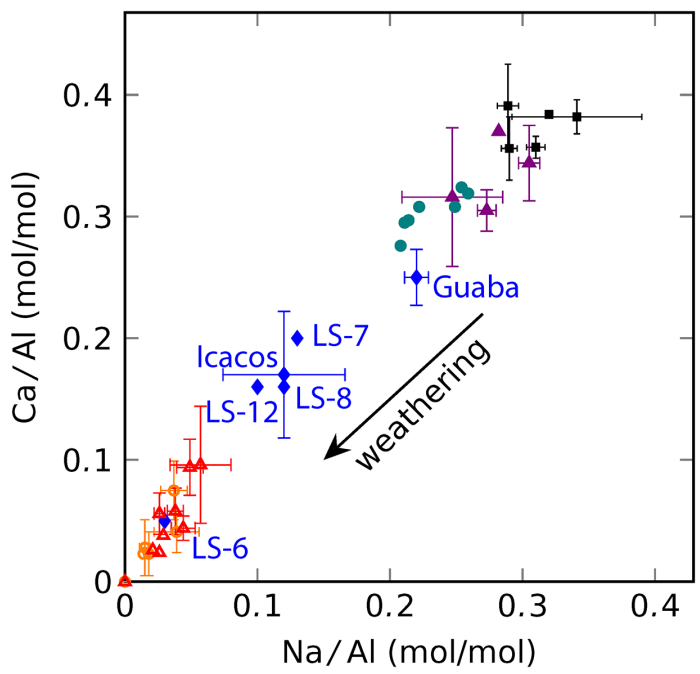

Figure 1 (a) Study locations at Río Icacos watershed in Puerto Rico. Colours indicate elevation, which are from USGS 3D Elevation Program through Open Topography. (b) Sampling location of seep sediments. Aerial imagery is from Esri (2017). (c) Na/Al and Ca/Al molar ratios of different solid end members (corestone, rindlet, seep sediment, stream sediment and saprolite/soil) determined through bulk analysis. Most $\mathrm{Na}$ and $\mathrm{Ca}$ are present in plagioclase in the bedrock, so as plagioclase weathers, the $\mathrm{Na} / \mathrm{Al}$ and $\mathrm{Ca} / \mathrm{Al}$ molar ratios decrease (Al is assumed to be not solubilised during plagioclase weathering). 

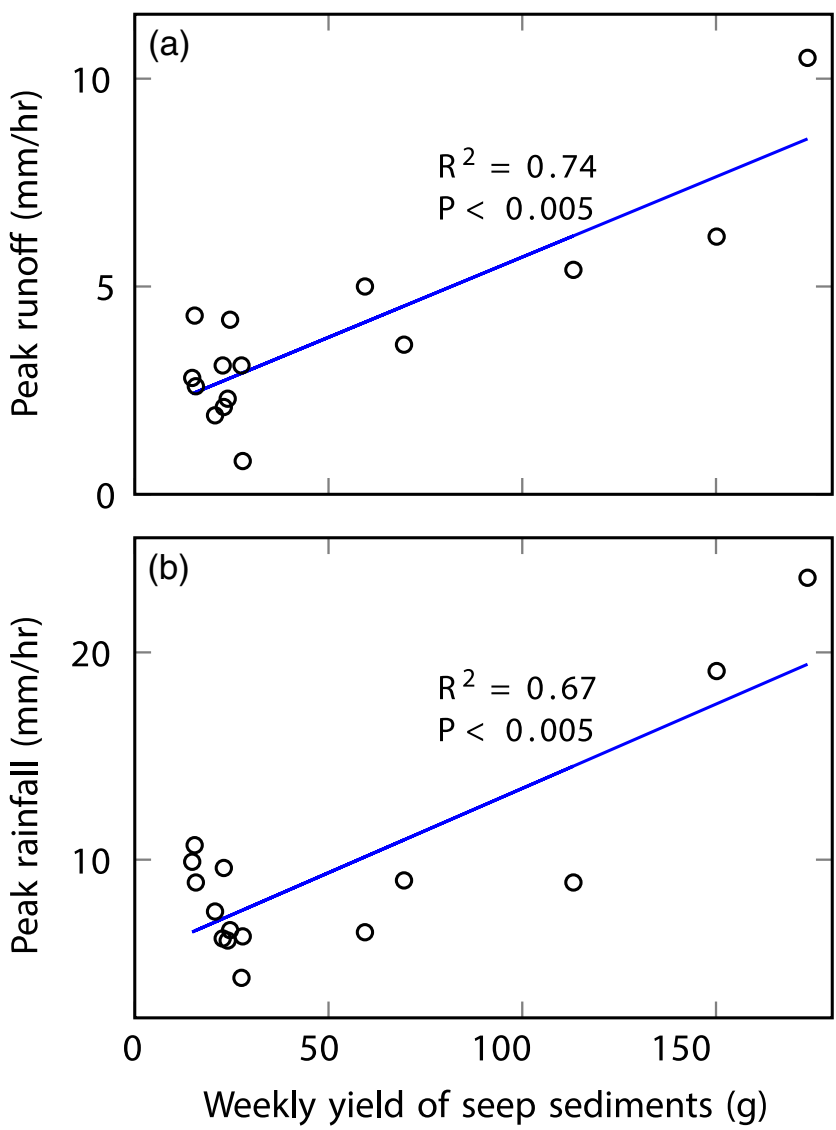

Figure 2 (a) Hourly peak runoff and (b) maximum rainfall intensity during the sampling week versus weekly accumulated mass of seep sediments. $\mathrm{P}=p$ value.

of Río Icacos and Quebrada Guaba (Fig. 1a), respectively, are sourced from seep sediments or similar less weathered materials (Supplementary Information).

\section{How Subsurface Particle Transport Occurs at Río Icacos}

We now consider how such seep sediments might form. In rocks, chemical processes can reduce rock cohesion and enhance the hydraulic conductivity and allow subsurface erosion to occur (Dunne, 1990; Lamb et al., 2006). In the following sections, we summarise observations that document these requirements for subsurface particle transport at Río Icacos: 1) fracture surfaces show enhanced chemical weathering, and 2) the fractured network can support sufficient flow velocities, driven by high hydraulic gradients, to entrain particles.

At Río Icacos, the oxidation of biotite is hypothesised to fracture rock at depth and create fracture-delineated rindlets around the outermost parts of each corestone (e.g., spheroidal weathering; Fletcher et al., 2006; Buss et al., 2008). The textures and compositions of the rindlet interiors are similar to that of the corestones because weathering roughly occurs from outside to inside (Fig. S-2). For example, the degree of alteration of the plagioclase and biotite increases dramatically toward the fracture surface (Fig. 3a-d). Alteration consists of fracturing of the plagioclase as calcic cores become increasingly dissolved or replaced by kaolinite (Fig. 3c). Biotite grains, which become partially to fully altered to vermiculite, increasingly exfoliate parallel to the cleavage plane at the rindlet edges (Fig. 3d). Also, the dissolution of plagioclase (Fig. 3a,c) and exfoliation of biotite (Fig. 3b,d) make these grains easy to detach physically.

Figure 4 exemplifies some of these characteristics. Elemental compositions of plagioclase grains in corestones plot on the mixing line of sodium-rich and calcium-rich plagioclase, showing no chemical weathering (Fig. 4). In contrast, the chemical compositions of plagioclase grains located at the exterior of rindlets span a wide range from unaltered plagioclase to kaolinite and gibbsite, and more than half of the grains are altered. These altered compositions approach that of seep sediments (Fig. 4). We infer that the seep sediments likely originated from the fracture surfaces.

Some of these observations may explain previous geophysical observations at Río Icacos. Ground penetrating radar (GPR) surveys indicated that eroding channels in the hillside leading to the river are usually co-located with vertical zones of enhanced GPR reflection. These were interpreted as deep fracture zones filled with rindletted corestones (Comas et al., 2019). Field measurements across these fracture zones showed coincident decreases in terrain conductivity and increases in magnetic susceptibility (Comas et al., 2019). To test what might cause this, we conducted magnetic susceptibility (MS) measurements in the laboratory and observed that the MS values decreased from corestones $\approx$ rindlets $>$ seep sediments $>$ soils (Table S-1). The decrease of MS is likely due to depletion of magnetite during weathering as documented by XRD (Supplementary Information); these measurements also showed that clay minerals (known to generally show relatively high electrical conductivity, EC (Palacky, 1987)) are enriched in seep sediments (Table S-2). These new data therefore show that the low EC in fracture zones could be caused by loss of particles like the clay-rich seep sediments while the high MS could be caused by retention of magnetite in the corestones and rindlets as seep sediment-like particles are removed.

Another geomorphological characteristic, amphitheatreshaped headwalls throughout the Río Icacos, provides additional evidence of seepage erosion (Harrison et al., 2020). For example, the steep slopes of headwalls around the sampled seep $\left(27-60^{\circ}\right)$ should provide a sufficient hydraulic gradient for subsurface particle flow. Hydrologic calculations also suggest that the size of fracture apertures is large enough to accommodate the size of seep sediments (Supplementary Information). In fact, during drilling in the quartz diorite, movement of particles in the subsurface between boreholes separated by $1 \mathrm{~m}$ has even been noted (Orlando, 2014).

\section{Fracture Surfaces are Hot Spots for Weathering and Erosion}

The chemical weathering rate of silicates as indicated by the riverine flux at Río Icacos is among the highest reported for granitoid watersheds (White and Blum, 1995). However, the high weathering rate at Río Icacos cannot be fully explained by the humid tropical climate since the rate is 4 to 20 times higher than other granitoid watersheds in tropical areas with high precipitation (Edmond et al., 1995; von Blanckenburg et al., 2004; Braun et al., 2012). The high weathering flux at Río Icacos has previously been attributed to the interconnected fractures that allow fast infiltration of oxygenated meteoric water that can accelerate weathering at multiple depths (e.g., Fletcher et al., 2006). Our study suggests that the transport of sand-sized particles through fractures at Río Icacos is an under-appreciated mechanism that exposes fresh particle surfaces to weathering fluids. Subsurface particle transport has not been previously invoked to explain the 10 fold discrepancies between short term denudation rates 

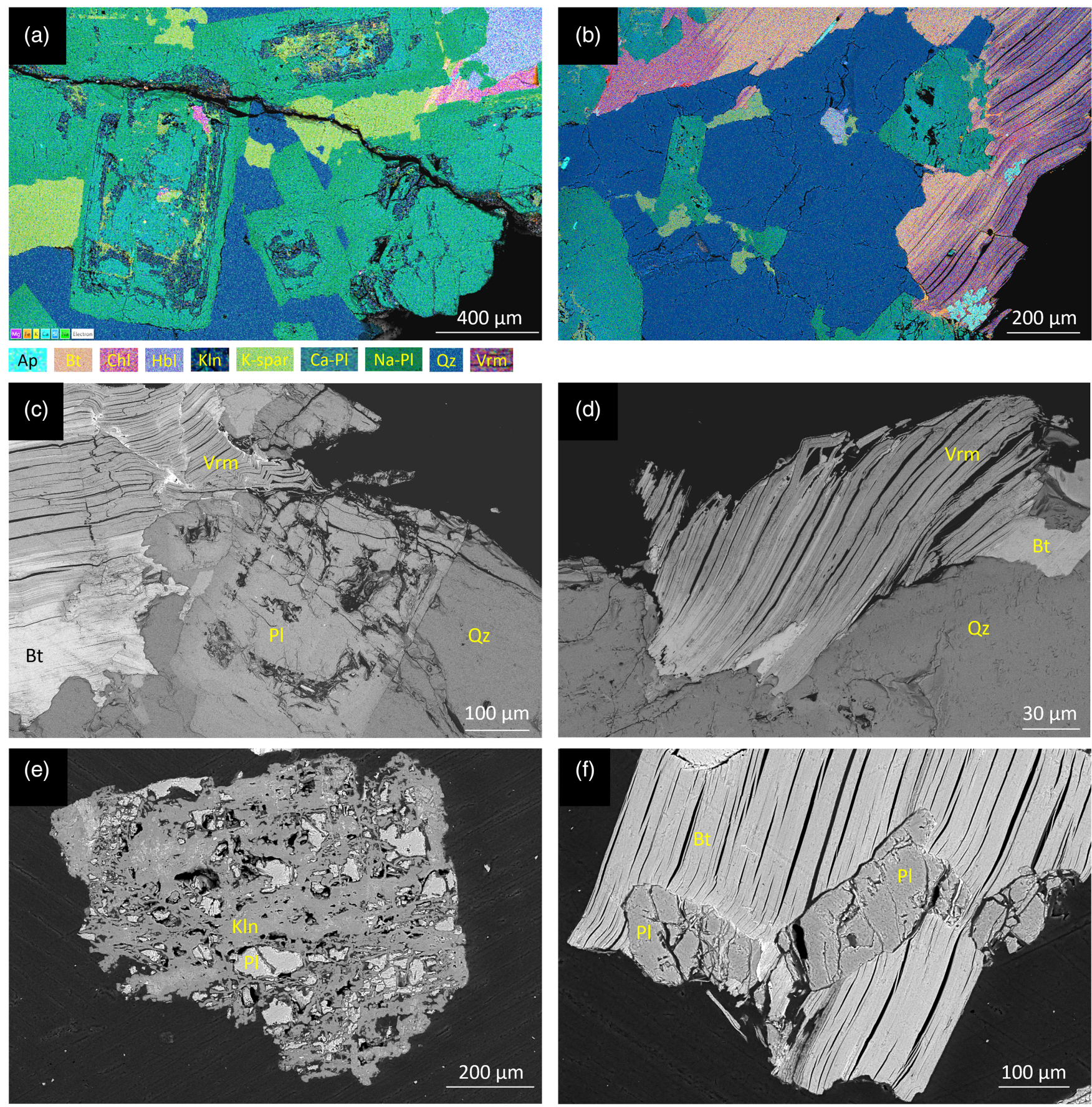

Figure $3(\mathbf{a}, \mathbf{b})$ Elemental maps and $(\mathbf{c}-\mathbf{f})$ backscattered electron images of the edge of rindlets $(\mathbf{a}-\mathbf{d})$ and seep sediments $(\mathbf{e}, \mathbf{f})$. The rindlet sample is from borehole LGW1 at 5.38-5.40 metres below land surface (LGW1 1-20) and the seep sediments were collected during August 916, 2016 (0.85-2.56 mm size fraction). Ap: apatite, Bt: biotite, Chl: chlorite, Hbl: hornblende, Kln: kaolinite, K-spar: K-feldspar, Pl: plagioclase, Qz: quartz, Vrm: vermiculite.

inferred from solid loads at stream gages (Stallard, 2012) and the long term denudation rates inferred from cosmogenic ${ }^{10} \mathrm{Be}$ (Brown et al., 1995). The stream sediments of Río Icacos are enriched in cosmogenic ${ }^{10} \mathrm{Be}$ from soils, but also contain seep sediments that do not contain ${ }^{10} \mathrm{Be}$ due to delivery from depth. Whether this means that denudation rates are underestimated remains to be explored.

Chemical weathering in fractured rocks has been relatively well studied. However, our understanding of particle transport through fractures is very limited because it is based on only a few studies such as those in carbonate (Levenson and
Emmanuel, 2017) or carbonate-rich shale lithologies (Deng et al., 2017). The significance of subsurface particle transport depends on disaggregation related to weathering of the fracture surface, the size of the particles relative to the fracture apertures, the fracture connectivity, and the hydraulic gradient. Subsurface particle transport is an under-appreciated process that likely shapes the deep critical zone and promotes chemical and physical weathering in mountainous areas with well developed fracture networks like the Luquillo Mountains. More investigations are needed to characterise particle transport by subsurface flow through different fracture geometries, in different lithologies, and at different temporal and spatial scales. 


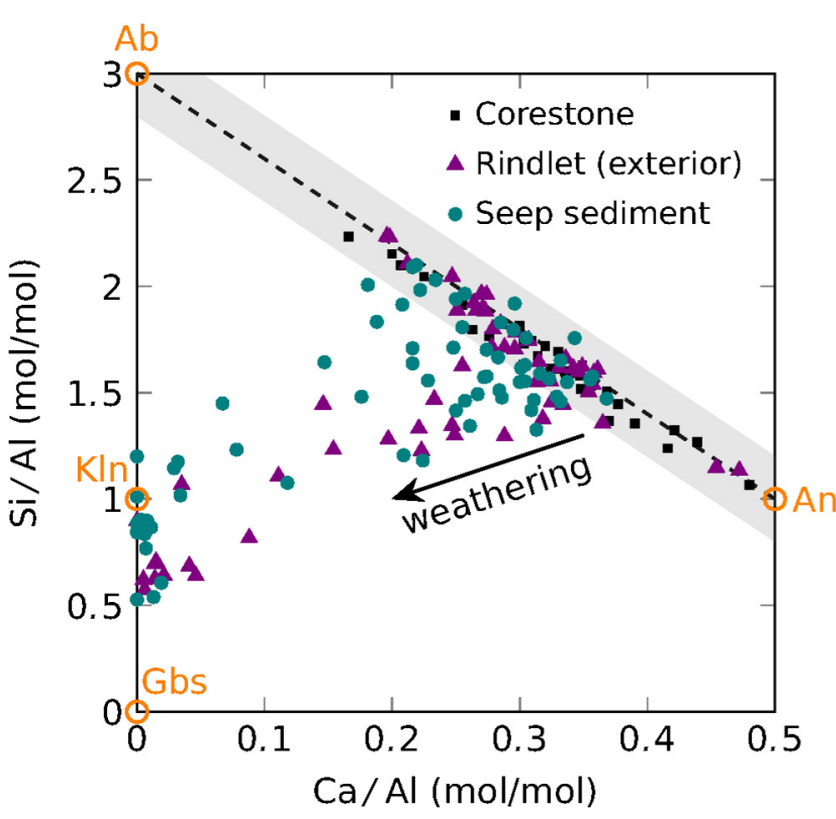

Figure $4 \mathrm{Si} / \mathrm{Al}$ and $\mathrm{Ca} / \mathrm{Al}$ molar ratios determined by scanning electron microscopy energy dispersive X-ray spectroscopy (EDS) on individual plagioclase grains from different solid end members (corestone, rindlet and seep sediment). The orange circles represent sodium-rich (albite, $\mathrm{Ab}$ ) and calcium-rich (anorthite, An) plagioclase and typical weathering products of plagioclase such as gibbsite (Gbs) and kaolinite (KIn). The dashed line represents solid solution mixing of $A b$ and An. Shaded zone shows one standard deviation of uncertainty in $\mathrm{Ca} / \mathrm{Al}$ molar ratios assuming the relative error of EDS measurement is $5 \%$. Therefore, the points within the shaded zone are considered as unaltered plagioclase.

\section{Acknowledgements}

We thank technical support from the Materials Characterization Laboratory and Laboratory for Isotopes and Metals in the Environment at the Pennsylvania State University. We thank Jean-Marc Baele and an anonymous reviewer for helpful comments. This work was funded by the National Science Foundation Luquillo Critical Zone Observatory (NSF-LCZO), Grant EAR 1331841 to Bill McDowell.

Editor: Sophie Opfergelt

\section{Additional Information}

Supplementary Information accompanies this letter at https:// www.geochemicalperspectivesletters.org/article2127.

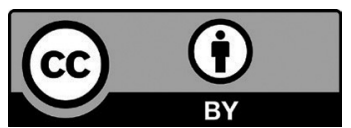

(C) 2021 The Authors. This work is distributed under the Creative Commons Attribution 4.0 License, which permits unrestricted use, distribution, and reproduction in any medium, provided the original author and source are credited. Additional information is available at http://www.geochemicalperspectivesletters.org/ copyright-and-permissions.

Cite this letter as: Gu, X., Kim, H., Hynek, S., Thompson, A., Brantley, S.L. (2021) Subsurface particle transport shapes the deep critical zone in a granitoid watershed. Geochem. Persp. Let. 19, 13-18.

\section{References}

Bern, C.R., Thompson, A., Chadwick, O.A. (2015) Quantification of colloidal and aqueous element transfer in soils: The dual-phase mass balance model. Geochimica et Cosmochimica Acta 151, 1-18.

Braun, J.-J., Marechal, J.-C., Riotte, J., Boeglin, J.-L., Bedimo Bedimo, J.-P., Ndam Ngoupayou, J.R., Nyeck, B., Robain, H., Sekhar, M., Audry, S., Viers, J. (2012) Elemental weathering fluxes and saprolite production rate in a Central African lateritic terrain (Nsimi, South Cameroon). Geochimica et Cosmochimica Acta 99, 243-270.

Brocard, G.Y., Willenbring, J.K., Scatena, F.N., Johnson, A.H. (2015) Effects of a tectonically-triggered wave of incision on riverine exports and soil mineralogy in the Luquillo Mountains of Puerto Rico. Applied Geochemistry 63, 586-598.

Brown, E.T., Stallard, R.F., Larsen, M.C., Raisbeck, G.M., Yiou, F. (1995) Denudation rates determined from the accumulation of in situ-produced ${ }^{10} \mathrm{Be}$ in the Luquillo Experimental Forest, Puerto Rico. Earth and Planetary Science Letters 129, 193-202.

Buss, H.L., SAK, P.B., WebB, S.M., BrantLey, S.L. (2008) Weathering of the Rio Blanco quartz diorite, Luquillo Mountains, Puerto Rico: Coupling oxidation, dissolution, and fracturing. Geochimica et Cosmochimica Acta 72, 4488-4507.

Chadwick, O.A., BRIMHALl, G.H., Hendricks, D.M. (1990) From a black to a gray box-a mass balance interpretation of pedogenesis. Geomorphology 3, 369-390.

Comas, X., Wright, W., HyneK, S.A., Fletcher, R.C., Brantley, S.L. (2019) Understanding fracture distribution and its relation to knickpoint evolution in the Rio Icacos watershed (Luquillo Critical Zone Observatory, Puerto Rico) using landscape-scale hydrogeophysics. Earth Surface Processes and Landforms 44, 877-885.

Deng, H., Voltolini, M., Molins, S., Steferel, C., DePaolo, D., Ajo-Frankin, J., YANG, L. (2017) Alteration and erosion of rock matrix bordering a carbonate-rich shale fracture. Environmental Science \& Technology 51, 8861-8868.

Dosseto, A., Buss, H.L., Chabaux, F. (2014) Age and weathering rate of sediments in small catchments: The role of hillslope erosion. Geochimica et Cosmochimica Acta 132, 238-258.

DunNe, T. (1990) Hydrology mechanics, and geomorphic implications of erosion by subsurface flow. In: Higgins, C.G., CoATES, D.R. (Eds.) Groundwater geomorphology: The role of subsurface water in Earth-surface processes and landforms. Geological Society of America, Boulder, 1-28.

Edmond, J.M., Palmer, M.R., Measures, C.I., Grant, B., Stallard, R.F. (1995) The fluvial geochemistry and denudation rate of the Guayana Shield in Venezuela, Colombia, and Brazil. Geochimica et Cosmochimica Acta 59, 3301-3325.

ESRI (2017) "World Imagery" [imagery]. 1:6,700 scale. "World Imagery". October 24, 2017. https://www.arcgis.com/home/item.html?id= 10df2279f9684e4a9f6a7f08febac2a9. (September 16, 2021).

FleTCheR, R.C., Buss, H.L., BrantLEY, S.L. (2006) A spheroidal weathering model coupling porewater chemistry to soil thicknesses during steady-state denudation. Earth and Planetary Science Letters 244, 444-457.

Harrison, E.J., Brocard, G.Y., Gasparini, N.M., Lyons, N.J., Willendring, J.K. (2020) Seepage erosion in the Luquillo Mountains, Puerto Rico, relict landscapes. Journal of Geophysical Research: Earth Surface 125, e2019JF005341.

HyneK, S., Comas, X., BrantLeY, S.L. (2017) The effect of fractures on weathering of igneous and volcaniclastic sedimentary rocks in the Puerto Rican tropical rain forest. 15th Water-rock Interaction International Symposium, Wri-15. 972-975.

KIM, H., Gu, X., BRANTLEY, S.L. (2018) Particle fluxes in groundwater change subsurface shale rock chemistry over geologic time. Earth and Planetary Science Letters 500, 180-191.

Lamb, M.P., Howard, A.D., Johnson, J., Whipple, K.X., Dietrich, W.E., Perron, J.T. (2006) Can springs cut canyons into rock? Journal of Geophysical Research: Planets 111, E07002.

Levenson, Y., Emmanuel, S. (2017) Repulsion between calcite crystals and grain detachment during water-rock interaction. Geochemical Perspectives Letters 3, 133-141.

OrLANDO, J. (2014) The anatomy of weathering profiles on different lithologies in the tropical forest of northeastern Puerto Rico: from bedrock to clouds. Master thesis: Pennsylvania State University.

PALACKY, G.J. (1987) Resistivity characteristics of geologic targets. In: Nabighian, M.N. (Ed.) Electromagnetic Methods in Applied Geophysics. Society of Exploration Geophysicists, Tulsa, 52-129.

Riebe, C.S., Hahm, W.J., Brantley, S.L. (2017) Controls on deep critical zone architecture: a historical review and four testable hypotheses. Earth Surface Processes and Landforms 42, 128-156. 
Shanley, J.B., McDowell, W.H., Stallard, R.F. (2011) Long-term patterns and short-term dynamics of stream solutes and suspended sediment in a rapidly weathering tropical watersheds. Water Resources Research 47, W07515.

STALLARD, R.F. (2012) Weathering, landscape equilibrium, and carbon in four watersheds in eastern Puerto Rico. USGS Professional Paper 1789-H.

von Blanckenburg, F., Hewawasam, T., KubiK, P.W. (2004) Cosmogenic nuclide evidence for low weathering and denudation in the wet, tropical highlands of Sri Lanka. Journal of Geophysical Research: Earth Surface 109, F03008.

WHITE, A.F., BLUM, A.E. (1995) Effects of climate on chemical weathering in watersheds. Geochimica et Cosmochimica Acta 59, 1729-1747.

White, A.F., Blum, A.E., Schulz, M.S., Vivit, D.V., Stonestrom, D.A., Larsen, M., MurPHY, S.F., EBERL, D. (1998) Chemical weathering in a tropical watershed, Luquillo mountains, Puerto Rico: I. Long-term versus short-term weathering fluxes. Geochimica et Cosmochimica Acta 62, 209-226. 